Article

\title{
Ferrous Magnetic Nanoparticles for Arsenic Removal from Groundwater
}

\author{
Corazón G. Morales-Amaya ${ }^{1}$, María T. Alarcón-Herrera ${ }^{1} \mathbb{D}$, Pablo D. Astudillo-Sánchez ${ }^{2}$, \\ Samuel A. Lozano-Morales ${ }^{3, *}$, Liliana Licea-Jiménez ${ }^{4}$ iD and Liliana Reynoso-Cuevas ${ }^{5, *(D)}$
}

1 Centro de Investigación en Materiales Avanzados, Departamento de Ingeniería Sustentable, Calle CIMAV 110, Ejido Arroyo Seco, Durango 34147, Mexico; corazon.morales@cimav.edu.mx (C.G.M.-A.); teresa.alarcon@cimav.edu.mx (M.T.A.-H.)

2 Departamento de Ciencias Básicas y Aplicadas, Centro Universitario de Tonalá, Av. Nuevo Periférico Ote., Tonalá 45425, Mexico; pablo.astudillo@academicos.udg.mx

3 Cátedras-CONACYT, Centro de Investigación en Química Aplicada (CIQA), Blvd. Enrique Reyna 140, Saltillo 25294, Mexico

4 Centro de Investigación en Materiales Avanzados, S.C. Alianza Norte 202, Parque de Investigación e Innovación Tecnológica PIIT, Apodaca 66628, Mexico; liliana.licea@cimav.edu.mx

5 Cátedras CONACYT, Centro de Investigación en Materiales Avanzados, Calle CIMAV 110, Ejido Arroyo Seco, Durango 34147, Mexico

* Correspondence: alejandro.lozano@ciqa.edu.mx (S.A.L.-M.); liliana.reynoso@cimav.edu.mx (L.R.-C.)

check for updates

Citation: Morales-Amaya., C.G.; Alarcón-Herrera, M.T.;

Astudillo-Sánchez, P.D.;

Lozano-Morales, S.A.; Licea-Jiménez,

L.; Reynoso-Cuevas, L. Ferrous

Magnetic Nanoparticles for Arsenic Removal from Groundwater. Water 2021, 13, 2511. https://doi.org/ $10.3390 /$ w13182511

Academic Editor: Laura Bulgariu

Received: 13 August 2021

Accepted: 10 September 2021

Published: 13 September 2021

Publisher's Note: MDPI stays neutral with regard to jurisdictional claims in published maps and institutional affiliations.

Copyright: (c) 2021 by the authors. Licensee MDPI, Basel, Switzerland. This article is an open access article distributed under the terms and conditions of the Creative Commons Attribution (CC BY) license (https:// creativecommons.org/licenses/by/ $4.0 /)$.

\begin{abstract}
Arsenic in water is currently a global concern due to the long-term exposure that could affect human health. In this study, magnetic nanoparticles (MNPs), $\mathrm{CoFe}_{2} \mathrm{O}_{4}$, and $\mathrm{MnFe}_{2} \mathrm{O}_{4}$ were successfully synthesized and applied to remove arsenic (As) from water. The MNPs were characterized using different techniques, such as scanning electron microscope (SEM), Brunauer-EmmetTeller (BET), and photoelectron spectroscopy (XPS). The nanoscale size and the specific surface area achieved a fast, selective, and high As adsorption capacity. MNPs have a mesoporous structure with a mean pore diameter of $5 \mathrm{~nm}$ and a mean particle size of $30 \mathrm{~nm}$. The adsorption capacity of these MNPs was determined through kinetic and equilibrium experiments, multilayer adsorption that obeyed the Freundlich model equation was observed, and the maximum adsorption capacities reached were $250 \mathrm{mg} / \mathrm{g}$ for $\mathrm{CoFe}_{2} \mathrm{O}_{4}$ and $230 \mathrm{mg} / \mathrm{g}$ for $\mathrm{MnFe}_{2} \mathrm{O}_{4}$. Furthermore, MNPs characteristics like regeneration and reuse, several $\mathrm{pH}$ tolerances, non-ion interference, and effective As removal from groundwater samples confirms the nanomaterials' potential for future applications in water treatment systems combined with magnetic separation.
\end{abstract}

Keywords: selective adsorption rate; maximum adsorption capacities; external magnetic field; arsenite removal; water purification systems

\section{Introduction}

Arsenic (As) pollution in water (groundwater) is one of the most critical environmental issues worldwide. Their most common species in aqueous environments are arsenite (As (III)), arsenate $(\mathrm{As}(\mathrm{V}))$, and elemental arsenic $\left(\mathrm{As}_{0}\right)$. Among these species, the As (III) compounds are more harmful than those constituted by As (V) [1]. Around the world, serious health effects have been observed in populations exposed to polluted water with As for an extended period. Permanent intake could cause the appearance of hyperkeratosis and arsenicosis (chronic endemic regional hydroarsenism, HACRE) [2]. Therefore, the World Health Organization (WHO) and the United States Protection Agency (EPA) approved $10 \mu \mathrm{g} / \mathrm{L}$, in the case of drinking water, as the As permissive limit, in order to avoid health effects [3].

According to the literature, different countries have reported arsenic in water in concentrations above the recommended limits, such as the United States, China, Chile, Bangladesh, Taiwan, México, Argentina, Poland, Canada, Hungary, and New Zealand [4]. 
In Latin America, the As presence in groundwater by geogenic origin is the main As source, and severe health problems due to water consumption with a high As content has been reported [2]. In Mexico, most of the population is exposed to a high As concentration in water; although As is classified as a carcinogenic contaminant of Group I [5], the Official Mexican Standard allows $25 \mu \mathrm{g} / \mathrm{L}$ (NOM-127-SSA1-1994). Therefore, it is important to improve or develop suitable methodologies for As removal in drinking water to values under innocuous limits.

Several technologies have been developed for the treatment and removal of heavy metals in water [1,6]. Traditional treatment processes include coprecipitation [7], ion exchange [8], membrane separation [9], filtration/ultrafiltration [10], electrocoagulation [11], reverse osmosis [12], dialysis/electrodialysis [13], etc. Some of these processes highlight advantages such as chemical precipitation results in very efficient metal removal. The chemical precipitation method is simple to operate and does not require expensive equipment [14]. Ion exchange, electrodialysis, and electrochemistry have the ability to selectively remove the pollutant eVen simultaneously with organic pollutants. However, each process has some inherent disadvantages. For example, chemical precipitation generates a large amount of by-product in the form of sludge, resulting in a secondary pollutant. Ion exchange, the electrochemical process, membrane filtration, and electrodialysis have high operating and maintenance costs.

Adsorption is a promising method as it represents an easy-to-use, low-cost, and lowby-product-generation technique. Furthermore, it has been developed using synthetic and mineral removal materials [15-17]. Adsorption technology is a recognized method for removing heavy metals from water. Especially in developing countries where financial resources are an issue, this technique provides an easy way to remove heavy metals such as arsenic from water. Currently, magnetic hydroxyapatite nanocomposites, magnetic magnetite nanoparticles for $\mathrm{Cr}$ (VI) and $\mathrm{Cu}$ (II) coexisting in mixed solutions, and magnetic nanoparticles synthesized by greenways, etc., have been studied [18-20]. However, the adsorption efficiency depends on the type of adsorbents. This study aimed to determine the removal capacity of arsenite ions from natural water by magnetic nanoparticles $\left(\mathrm{CoFe}_{2} \mathrm{O}_{4}\right.$ and $\mathrm{MnFe}_{2} \mathrm{O}_{4}$ ). The performance of these MNPs was eValuated under numerous conditions, such as the stability of the MNPs at different $\mathrm{pH}$ values, the contact time in the aqueous solution, the adsorbent dose, and the initial concentration of As (III), which could affect the adsorption process.

\section{Materials and Methods}

\subsection{Nanoparticles Synthesis}

All the precursors used in the experiments (analytical reactive grade) were used without further purification. The MNPs were prepared by the chemical coprecipitation method [21]. For the synthesis of the $\mathrm{MnFe}_{2} \mathrm{O}_{4} \mathrm{MNPs}, \mathrm{Fe}\left(\mathrm{NO}_{3}\right)_{3} \bullet 9 \mathrm{H}_{2} \mathrm{O}$ (Sigma AldrichQuímica, S.L Toluca, México), and $\mathrm{MnSO}_{4} \bullet \mathrm{H}_{2} \mathrm{O}$ (Fermont-Productos químicos Monterrey S.A. de C.V. Monterrey, N.L.México J.T. Baker), precursors were dissolved in $5 \mathrm{~mL}$ of deionized water and $\mathrm{HCl}(1 \mathrm{~mL}, 1 \mathrm{M}$, Fermont), with a stoichiometry ratio of 2:1. First, the solution was mixed and vigorously stirred. Then, $100 \mathrm{~mL}$ of $\mathrm{NaOH}$ (Fermont) was added dropwise to $3 \mathrm{M}$. Once the addition was complete, it was brought to $90{ }^{\circ} \mathrm{C}$ for $60 \mathrm{~min}$. The same procedure was applied for $\mathrm{CoFe}_{2} \mathrm{O}_{4}$ MNPs using $\mathrm{CoSO}_{4} \bullet 7 \mathrm{H}_{2} \mathrm{O}$ (J.T. Baker Avantor Performance Materials, Inc., Center Valley, PA, USA). Next, the MNPs were recovered from the solution with a magnet and repeatedly rinsed with distilled water until neutral $\mathrm{pH}$. Afterward, the values of $\mathrm{pH}$ were adjusted to $6,7,8$, and 8.5. Finally, the products were taken to the oven at $100{ }^{\circ} \mathrm{C}$ for $24 \mathrm{~h}$ to subsequently grind them.

\subsection{MNPs Characterization}

The size and morphology of the MNPs were observed by scanning electron microscopy (SEM), using an FEI Nova NanoSem200 with a low vacuum detector. A PANalytical X-ray diffractometer model Empyrean of Malvern with a K-Alpha $\mathrm{Cu}$ anode of $1.54 \mathrm{~nm}$ at an 
amperage of $40 \mathrm{~mA}$ and a $45 \mathrm{kV}$ voltage, with a scanning step of 0.02 in $2 \theta$ degrees, was used to know the crystal structure of the MNPs. The specific surface area was determined by the Brunauer, Emmett, and Teller (BET) method, using the Quantachrome Nova Corporation 1000 series equipment. The samples were degassed in a vacuum at $150{ }^{\circ} \mathrm{C}$ for $10 \mathrm{~h}$. Furthermore, photoelectron spectroscopy (XPS) analyses were carried out with a Thermo Scientific Escalab 250Xi instrument. During analysis, the base pressure was $\sim 10^{-10} \mathrm{mbar}$, and the photoelectrons were generated with the $\mathrm{Al} \mathrm{K} \alpha(1486.68 \mathrm{eV}) \mathrm{X}$-ray source with a monochromator and a spot size of $650 \mu \mathrm{m}$. The $\mathrm{X}$-ray voltage and power were $14 \mathrm{kV}$ and $350 \mathrm{~W}$, respectively. The high-resolution spectra's acquisition conditions were $20 \mathrm{eV}$ pass energy, $45^{\circ}$ take-off angle, and $0.1 \mathrm{eV} / \mathrm{step}$. The recorded photoelectron peaks were analyzed with the Avantage Software V 5.4. The magnetic properties of MNP powder samples were analyzed at room temperature $\left(26^{\circ} \mathrm{C}\right)$ with an AGM MICROMAG magnetometer. $\mathrm{Z}$ potential (PZ) was determined as a $\mathrm{pH}$ function with distilled water with a Microtrac Zeta Check with a $400 \mu \mathrm{m}$ piston, five times for each sample.

\subsection{Adsorption Experiments}

Adsorption experiments were performed to eValuate the MNPs' arsenic adsorption capacities. Kinetic experiments were carried out at different adsorbent doses $(0.01$ and $0.1 \mathrm{~g} / \mathrm{L})$, different contact times $(1,15,30,60$, and $90 \mathrm{~min})$, and different $\mathrm{pH}(6,7,8$, and 8.5) by shaking the solution ( $480 \mathrm{rpm}$ ) with an initial As concentration of $45 \mu \mathrm{g} / \mathrm{L}$ at room temperature.

MNPs' separation was carried out through the \#42 filter, and the total As final concentration was determined by a GBS atomic absorption spectrophotometer (GBC XplorAA Dual model Avanta P) coupled to a hydride generator (HG-AAS) with flame (air-acetylene). Three milliliters of concentrated $\mathrm{HCl}$ and $3 \mathrm{~mL}$ of $\mathrm{Kl}$ were added to the samples and allowed to stand for $3 \mathrm{~h}$ before the analysis, according to the method's procedure.

Finally, ion competition experiments were carried out at an initial As(III) concentration of $40 \mu \mathrm{g} / \mathrm{L}$. The solution was prepared using $\mathrm{NaAsO}_{2}$ (J.T. Baker) as an analytical grade reagent, dissolved in deionized water, and the different cations were added separately.

The groundwater As adsorption efficiency was eValuated in natural groundwater. Samples were acquired from the San Luis well (Durango, México). Test samples of $50 \mathrm{~mL}$ with an adsorbent dose of $0.1 \mathrm{~g}\left(\mathrm{CoFe}_{2} \mathrm{O}_{4} / \mathrm{MnFe}_{2} \mathrm{O}_{4}\right)$ were used, and the total contact time with shaking ( $480 \mathrm{rpm}$ ) was $60 \mathrm{~min}$. Then, the MNPs were filtered by magnetic filtration, and the flasks were labeled for their analysis. The groundwater characteristics are given in Table 1.

Table 1. Physicochemical water characterization.

\begin{tabular}{|c|c|}
\hline Parameter & Value \\
\hline As $\mu \mathrm{g} / \mathrm{L}$ & 32.00 \\
\hline $\mathrm{pH}$ & 8.04 \\
\hline Conductivity ( $\mu \mathrm{s} / \mathrm{cm})$ & 542.50 \\
\hline Fluoride $(\mathrm{mg} / \mathrm{L})$ & 4.12 \\
\hline $\mathrm{Na}^{+}(\mathrm{mg} / \mathrm{L})$ & 46.14 \\
\hline $\mathrm{K}^{+}(\mathrm{mg} / \mathrm{L})$ & 7.94 \\
\hline $\mathrm{Ca}^{+}(\mathrm{mg} / \mathrm{L})$ & 61.00 \\
\hline $\mathrm{Mg}^{+}(\mathrm{mg} / \mathrm{L})$ & 1.54 \\
\hline $\mathrm{NO}_{3-}(\mathrm{mg} / \mathrm{L})$ & 37.50 \\
\hline $\mathrm{Cl}^{-}(\mathrm{mg} / \mathrm{L})$ & 23.14 \\
\hline $\mathrm{CO}_{3}^{2-}(\mathrm{mg} / \mathrm{L})$ & 0 \\
\hline $\mathrm{HCO}_{3}-(\mathrm{mg} / \mathrm{L})$ & 138.60 \\
\hline $\mathrm{SO}_{4}(\mathrm{mg} / \mathrm{L})$ & 59.76 \\
\hline Total alcalinity $\left(\mathrm{mg} \mathrm{CaCO}_{3} / \mathrm{L}\right)$ & 138.60 \\
\hline Hardness $(\mathrm{mg} / \mathrm{L})$ & $<5$ \\
\hline
\end{tabular}




\section{Results}

\subsection{Characterization of $\mathrm{CoFe}_{2} \mathrm{O}_{4}$ and $\mathrm{MnFe}_{2} \mathrm{O}_{4}$ Nanoparticles}

The size and morphology of the two magnetic nanoparticles synthesized were determined by scanning electron microscopy (SEM). According to the images and histograms, the samples consist of nanoparticles with relatively uniform size and quasi-spherical morphology (Figure 1a-d).

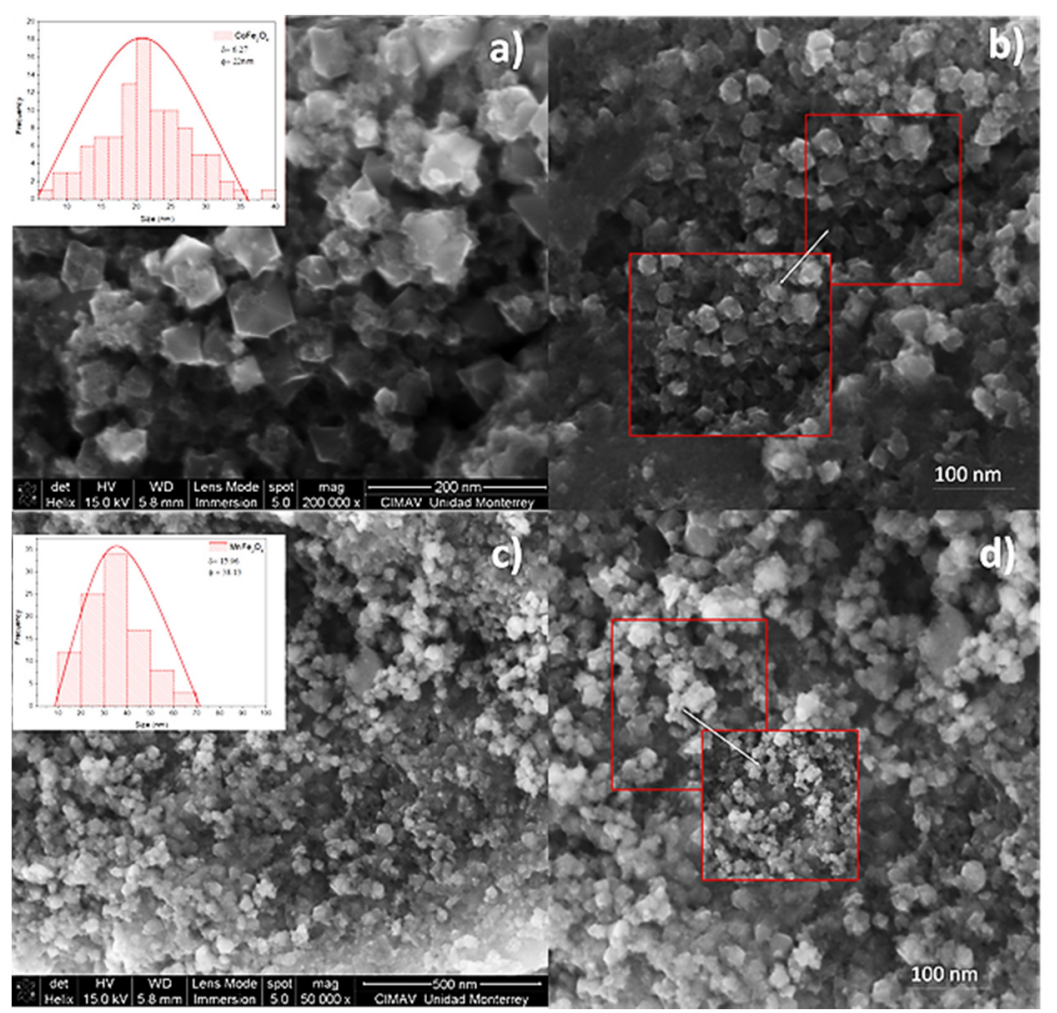

Figure 1. Scanning electron microscopy images, MNPs morphology: $\mathrm{CoFe}_{2} \mathrm{O}_{\mathbf{a}}(\mathbf{a}, \mathbf{b}), \mathrm{MnFe}_{2} \mathrm{O}_{4}(\mathbf{c}, \mathbf{d})$.

The size distribution was calculated using ImageJ software, and average sizes of 22 and $38 \mathrm{~nm}$ were obtained for $\mathrm{CoFe}_{2} \mathrm{O}_{4}$ and $\mathrm{MnFe}_{2} \mathrm{O}_{4}$, respectively. Regarding the BET results, the specific surface area values for $\mathrm{CoFe}_{2} \mathrm{O}_{4}$ and $\mathrm{MnFe}_{2} \mathrm{O}_{4}$ were 198.6 and $188.8 \mathrm{~m}^{2} / \mathrm{g}$, respectively. Moreover, the pore size of both MNPs was around $5.8 \mathrm{~nm}$. According to the IUPAC (International Union of Pure and Applied Chemistry), mesoporous materials are found in the range from 2 to $50 \mathrm{~nm}$; therefore, the MNPs synthesized in this study are mesoporous materials.

The XRD patterns of $\mathrm{CoFe}_{2} \mathrm{O}_{4}$ and $\mathrm{MnFe}_{2} \mathrm{O}_{4}$ are shown in Figure 2. Figure 2a shows the diffraction peaks for the $\mathrm{CoFe}_{2} \mathrm{O}_{4}$ sample, located at the $2 \theta$ values of $18^{\circ}, 30^{\circ}, 36^{\circ}, 43^{\circ}$, $57^{\circ}$, and $62^{\circ}$ with the respective crystal planes (111), (220), (311), (400), (511), and (400), corresponding with the card JCPDS-22-1086 [15]. Figure $2 \mathrm{~b}$ corresponds to the $\mathrm{MnFe}_{2} \mathrm{O}_{4}$ sample, and the peaks $2 \theta$ to $30.31^{\circ}, 36.60^{\circ}, 44.57^{\circ}, 58.68^{\circ}, 57.12^{\circ}$, and $65.78^{\circ}$ are indexed to planes (220), (311), (400), (511), and (440), matching the cubic structure centered on the face of $\mathrm{MnFe}_{2} \mathrm{O}_{4}$, according to the International center diffraction data card, JCPDS- 742403 [22]. 


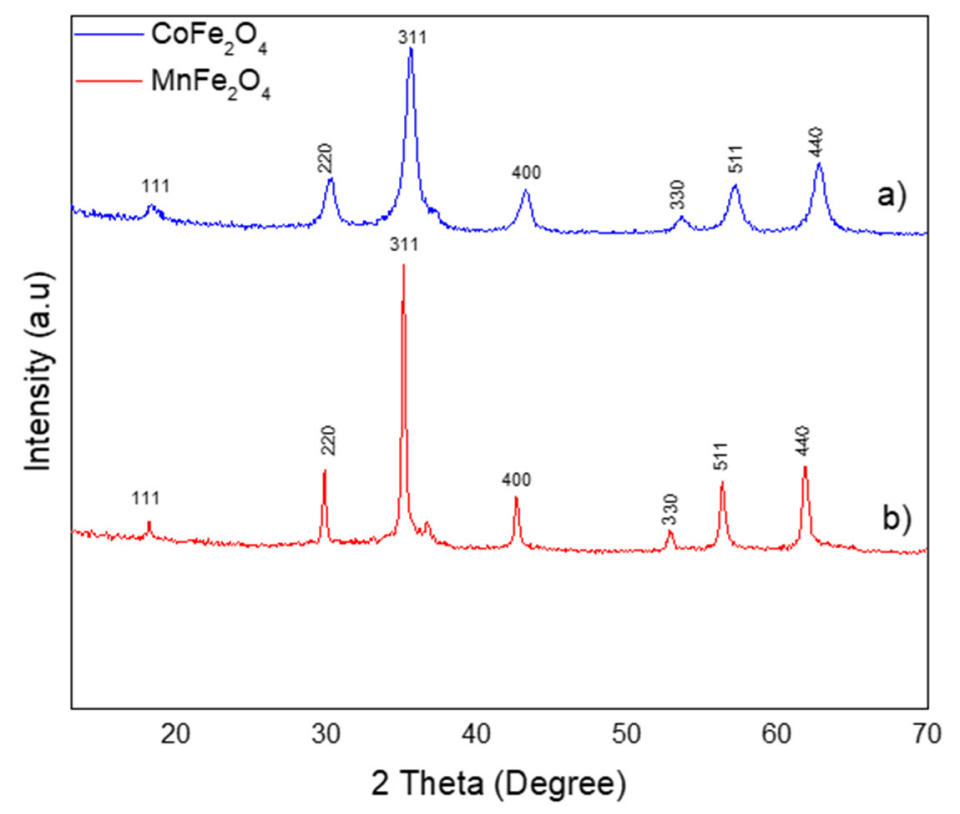

Figure 2. $\mathrm{XRD}$ patterns for (a) $\mathrm{CoFe}_{2} \mathrm{O}_{4}$ and (b) $\mathrm{MnFe}_{2} \mathrm{O}_{4}$.

In order to obtain the composition and chemical states of the MNPs, XPS measurements were carried out. As a result, the full survey spectra of $\mathrm{CoFe}_{2} \mathrm{O}_{4}$ and $\mathrm{MnFe}_{2} \mathrm{O}_{4}$ confirm the presence of $\mathrm{Co}, \mathrm{Fe}, \mathrm{Mn}$, and O elements, as shown in Figure A1.

The high-resolution spectra of the samples are shown in Figure 3a-f. The energy levels to analyze correspond to $\mathrm{Co} 2 \mathrm{p}, \mathrm{Fe} 2 \mathrm{p}$, and $\mathrm{O} 1 \mathrm{~s}$ for the $\mathrm{CoFe}_{2} \mathrm{O}_{4}$ sample, and $\mathrm{Mn} 2 \mathrm{p}$, Fe 2p, and $\mathrm{O} 1 \mathrm{~s}$ for the $\mathrm{MnFe}_{2} \mathrm{O}_{4}$.
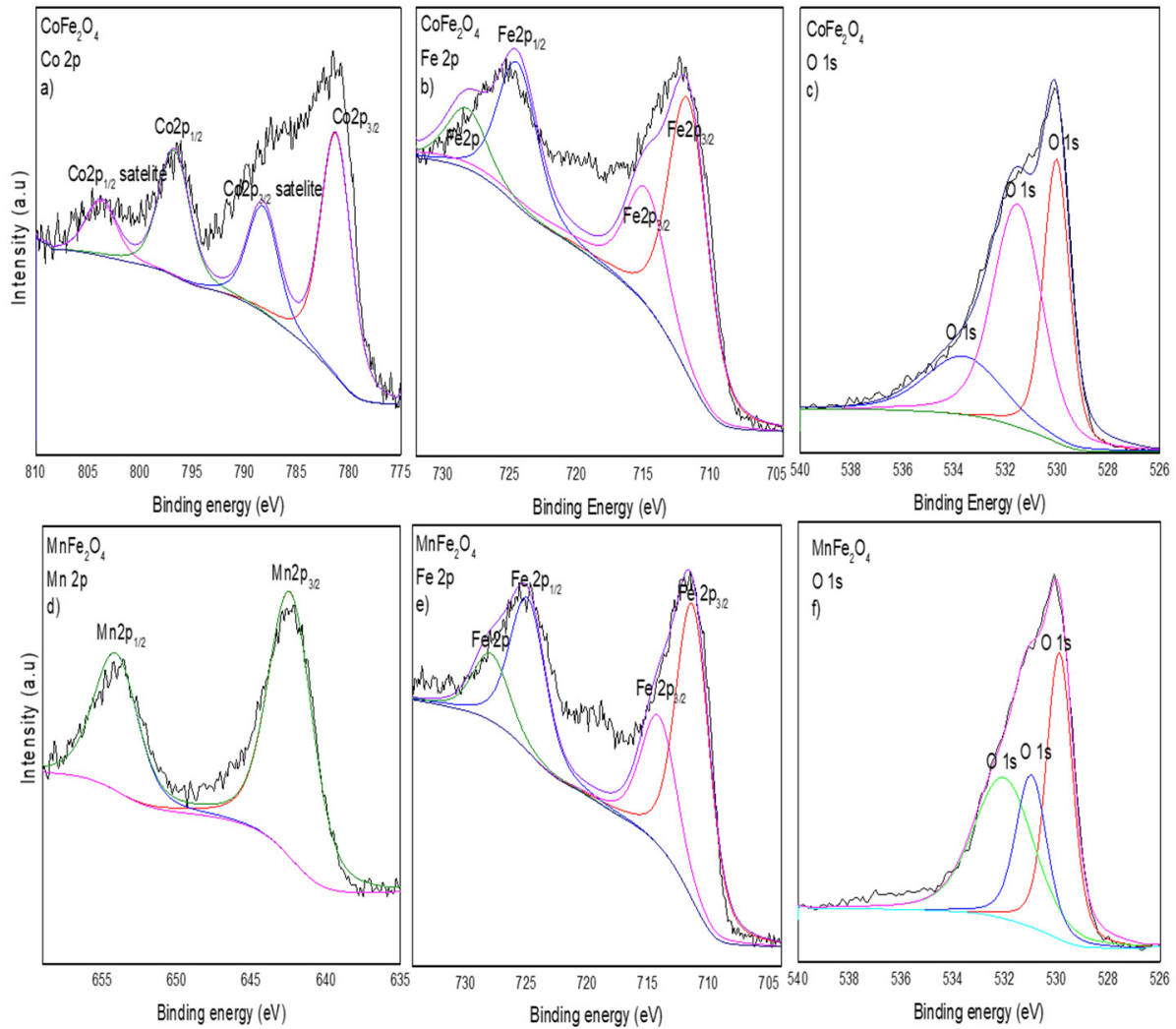

Figure 3. The high-resolution XPS spectra for (a-c) $\mathrm{CoFe}_{2} \mathrm{O}_{4}$ and (d-f) $\mathrm{MnFe}_{2} \mathrm{O}_{4}$. 
The high-resolution Co 2p spectrum shown in Figure 3a can be fitted with two spinorbit doublets and their corresponding satellite peaks. The binding energy of Co $2 p_{3 / 2}$ is found at $781.23 \mathrm{eV}$ with a satellite peak at $788.24 \mathrm{eV}$, while the binding energy of Co $2 \mathrm{p}_{1 / 2}$ is located at $796.73 .4 \mathrm{eV}$ and its satellite peak at $803.74 \mathrm{eV}$. Thus, the existence of $\mathrm{Co}^{2+}$ is suggested [23]. For the Fe $2 \mathrm{p}$ (Figure 3b), the binding energy at 711.64 and $724.44 \mathrm{eV}$ are assigned to $\mathrm{Fe} 2 \mathrm{p}_{3 / 2}$ and $\mathrm{Fe} 2 \mathrm{p}_{1 / 2}$, respectively, confirming the presence of $\mathrm{Fe}^{3+}$ in octahedral sites [23]. Furthermore, the signal at 714.80 is assigned to $\mathrm{Fe}^{3+}$ as tetrahedral species [23].

For the high-resolution $\mathrm{O} 1 \mathrm{~s}$ spectrum (Figure 3c), three signals are observed, whereby the main peak at $530.02 \mathrm{eV}$ is ascribed as a metal-oxygen bond and the remaining two peaks at $531.53 \mathrm{eV}$ and $533.64 \mathrm{eV}$ are assigned to oxygen from functional groups [23].

The high-resolution XPS spectra for $\mathrm{MnFe}_{2} \mathrm{O}_{4}$ are presented in Figure 3d-f. The XPS fitted spectra for Mn 2p (Figure 3d) reveal two main peaks located at $642.38 \mathrm{eV}$, which corresponds to $\mathrm{Mn} 2 \mathrm{p}_{3 / 2}$ and at $654.08 \mathrm{eV}$ attributed to $\mathrm{Mn} 2 \mathrm{p}_{1 / 2}$, and the separation between these two peaks is $11.7 \mathrm{eV}$, which corresponds to $\mathrm{Mn}^{2+}$ [24,25]. Fe 2p spectra (Figure 3e) show two main peaks at $711.29 \mathrm{eV}$ and $724.89 \mathrm{eV}$, which are attributable to $\mathrm{Fe} 2 \mathrm{p}_{3 / 2}$ and $\mathrm{Fe} 2 \mathrm{p}_{1 / 2}$, respectively, of $\mathrm{Fe}^{3+}[25,26]$. XPS fitted spectra of O1s in Figure $3 \mathrm{f}$ show three main peaks at $529.89 \mathrm{eV}$ attributed to Fe-O or Mn-O, at $530.98 \mathrm{eV}$ and $532.05 \mathrm{eV}$, ascribed to $\mathrm{C}-\mathrm{O}$ and $\mathrm{C}=\mathrm{O}$, respectively [25].

The MNPs hysteresis cycles were investigated to check the magnetization saturation degree. Figure 4a shows $\mathrm{CoFe}_{2} \mathrm{O}_{4}$ and $\mathrm{MnFe}_{2} \mathrm{O}_{4}$ powders results, where 58.80 and $48.40 \mathrm{emu} / \mathrm{g}$ were obtained, respectively. The high crystalline quality could be related to their superparamagnetic behavior [26]. In the absence of an external magnetic field, these particles have zero magnetization and less tendency to agglomerate [27] because the magnetization values remain and the field coercive is negligible.
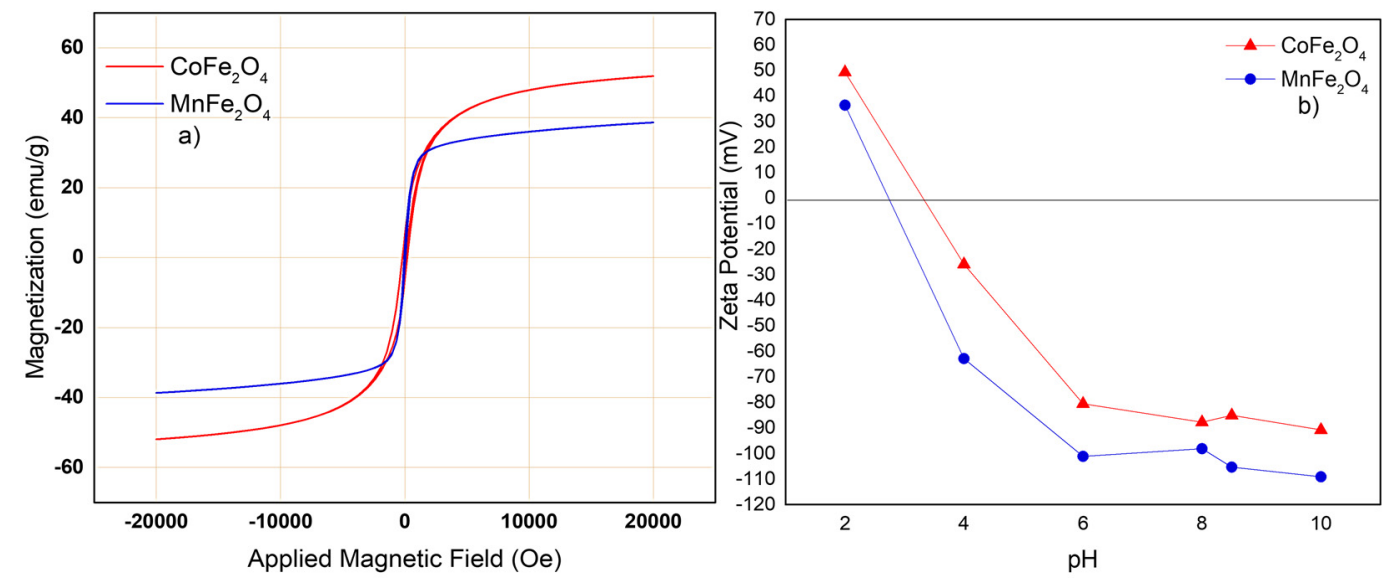

Figure 4. (a) Hysteresis cycle of $\mathrm{CoFe}_{2} \mathrm{O}_{4}$ and $\mathrm{MnFe}_{2} \mathrm{O}_{4}$, and (b) Zeta potential as a function of $\mathrm{pH}$ of $\mathrm{CoFe}_{2} \mathrm{O}_{4}$ and $\mathrm{MnFe}_{2} \mathrm{O}_{4}$.

Hence, these MNPs could be separated from the solution by applying an external magnetic field, making their recovery easy. When the external magnetic field is removed, these nanoparticles will quickly disperse.

Figure $4 \mathrm{~b}$ shows the synthesized MNPs zeta potential results as a function of the $\mathrm{pH}$. For $\mathrm{CoFe}_{2} \mathrm{O}_{4}$ and $\mathrm{MnFe}_{2} \mathrm{O}_{4}$, the difference between the $\mathrm{pH}$ values over the zeta potential is negligible. The MNPs' charge at $\mathrm{pH} 2$ is positive. On the other hand, for $\mathrm{pH}$ of 4, 6, 8, 8.5, and 10, the MNPs' surface charge is negative; so, the isoelectric point of these materials would be at $\mathrm{pH} 2$. Furthermore, at $\mathrm{pH}>4$, the slope of the line towards the negative charges is considerably increased. According to these results, the adsorption of positive ions in these materials would be fostered from $\mathrm{pH}>2$ because the surface charges are partially negative and will promote equilibrium with the MNPs' positive surface charge. This positive charge could be due to the presence of $\equiv \mathrm{Fe}-\mathrm{OH}^{2+}$ groups on the surface, 
while the negative surface charge of the MNPs particles above $\mathrm{pH}>2$ could be due to the $\equiv \mathrm{Fe}-\mathrm{O}-$ groups [28].

\subsection{Adsorptions Experiments}

Adsorption experiments were performed with two solutions. The first one was prepared with deionized water at an initial As concentration of $45 \mu \mathrm{g} / \mathrm{L}$, and the second one was the groundwater from the San Luis well (Durango, Dgo., Mexico).

Figure 5 shows the As(III) removal efficiency at two different adsorbent concentrations $(0.01$ and $0.1 \mathrm{~g} / \mathrm{L})$. The results show the adsorption capacity as a function of the adsorbent concentration, and the adsorption process is strongly linked to the surface area available for the adsorption $[29,30]$. With an adsorbent dose of $0.1 \mathrm{~g} / \mathrm{L}$, As(III) removal reaches $97 \%$ with $\mathrm{CoFe}_{2} \mathrm{O}_{4}$ and $94 \%$ with $\mathrm{MnFe}_{2} \mathrm{O}_{4}$. Besides, removal efficiency with the less adsorbent dose $(0.01 \mathrm{~g} / \mathrm{L})$ was 85 and $78 \%$, with $\mathrm{CoFe}_{2} \mathrm{O}_{4}$ - and $\mathrm{MnFe}_{2} \mathrm{O}_{4}$, respectively.

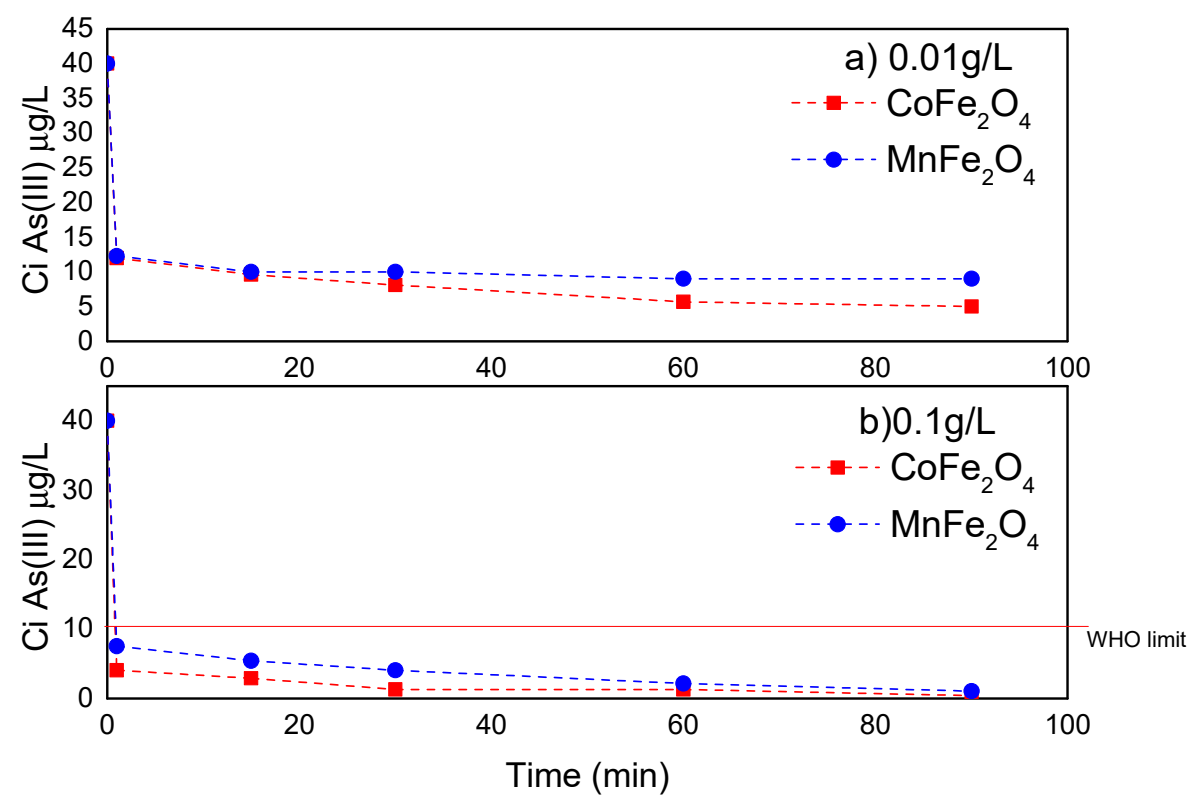

Figure 5. As adsorption with the two nanoparticles $\left(\mathrm{CoFe}_{2} \mathrm{O}_{4}\right.$ and $\left.\mathrm{MnFe}_{2} \mathrm{O}_{4}\right)$ at different contact times and adsorbent doses: (a) $0.01 \mathrm{~g} / \mathrm{L}$ and (b) $0.1 \mathrm{~g} / \mathrm{L}$.

Yang and Yin (2017) studied mesoporous $\mathrm{CoFe}_{2} \mathrm{O}_{4} @ M I L-100$ (Fe) MNPs, with an average diameter of $260 \mathrm{~nm}$, and their results have shown rapid and selective As adsorption (143.6 mg/g) [31], similar to the results shown in this study. Moreover, Zhang et al. (2011) reported that As adsorption with $\mathrm{CoFe}_{2} \mathrm{O}_{4}$ and $\mathrm{MnFe}_{2} \mathrm{O}_{4}$ depends on several parameters, such as $\mathrm{pH}$, initial As concentration, contact time, and the presence of interfering ions. The maximum adsorption capacities that they obtained for $\mathrm{As}(\mathrm{III})$ and $\mathrm{As}(\mathrm{V})$ were 94 and $90 \mathrm{mg} / \mathrm{g}$ with $\mathrm{MnFe}_{2} \mathrm{O}_{4}$, and 100 and $74 \mathrm{mg} / \mathrm{g}$ with $\mathrm{CoFe}_{2} \mathrm{O}_{4}$ [32].

In addition, with a less adsorbent dose $\left(\mathrm{CoFe}_{2} \mathrm{O}_{4}, 0.2 \mathrm{~g} / \mathrm{L}\right)$, Zhang (2010) reported $90 \%$ (As(III)) maximum removal efficiency in twelve hours [33]. In the present study, after $30 \mathrm{~min}$ with the adsorbent dose of $0.1 \mathrm{~g} / \mathrm{L}$, a final As concentration below $25 \mu \mathrm{g} / \mathrm{L}$ (Mexican regulations for drinking water [34]) was reached with both MNPs. In contrast, Podder (2015) reports $86 \% \mathrm{As}(\mathrm{III})$ removal with $\mathrm{MnFe}_{2} \mathrm{O}_{4}$ after $80 \mathrm{~min}$ and an adsorbent dose of $2 \mathrm{~g} / \mathrm{L}$ [34]. Furthermore, Iconaru (2016) reported maximum removal efficiency of $70 \%$ after $24 \mathrm{~h}$ of contact time with $\mathrm{Fe}_{3} \mathrm{O}_{4}(2 \mathrm{~g} / \mathrm{L})$ for $\mathrm{As}$ (III) [35].

Figure 6 shows the effect of contact time at different initial As(III) concentrations with both MNPs $\left(\mathrm{CoFe}_{2} \mathrm{O}_{4}, \mathrm{MnFe}_{2} \mathrm{O}_{4}\right)$ on $\mathrm{As}$ (III) removal. As we can see, the arsenic removal with both nanoparticles was independent of the initial arsenic concentration, achieving an As(III) adsorption higher than $90 \%$ in all cases in the first 10 min of treatment. Thus, in a contact time of $50 \mathrm{~min}$, up to $95 \%$ of the arsenic can be adsorbed for concentrations of 45 
and $50(\mu \mathrm{g} / \mathrm{L})$. The adsorbate removal was performed quickly in the early stages; then, the adsorption rate gradually declined until the equilibrium was reached in each case.

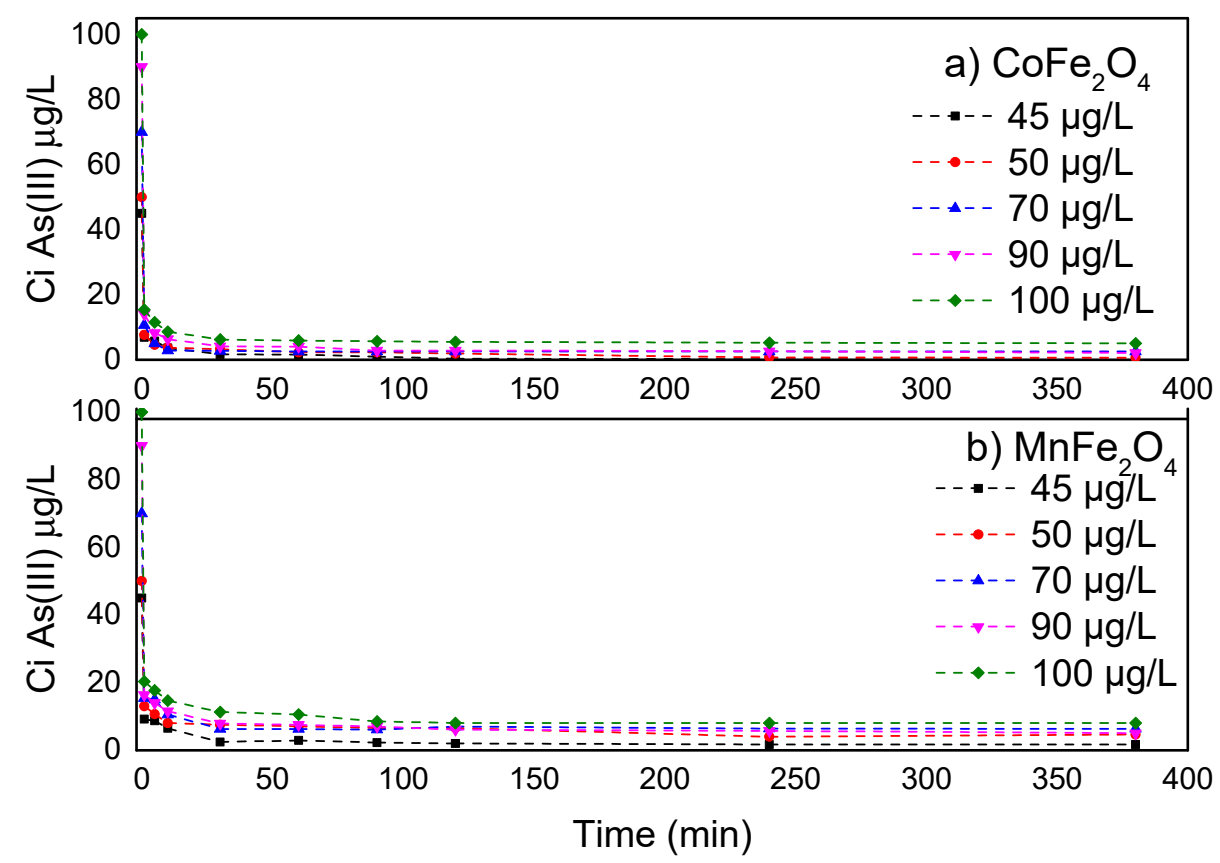

Figure 6. As(III) adsorption with respect to time (in minutes) of adsorbate-adsorbent contact of (a) $\mathrm{CoFe}_{2} \mathrm{O}_{4}$, (b) $\mathrm{MnFe}_{2} \mathrm{O}_{4}$.

Therefore, the reduction curves were simple, smooth, and continuous, which led to equilibrium and the possibility of multilayer coverage on the adsorbent surface [31].

The maximum removal of $\mathrm{As}(\mathrm{III})$ ions with $\mathrm{CoFe}_{2} \mathrm{O}_{4}$ and $\mathrm{MnFe}_{2} \mathrm{O}_{4}(98 \%$ and $95 \%$, respectively) was achieved after $30 \mathrm{~min}$ with an initial As concentration of $45 \mu \mathrm{g} / \mathrm{L}$. Podder et al. (2015) reported that the maximum adsorption of $\mathrm{As}(\mathrm{III})$ ions (Operating conditions: Ci $4 \mathrm{mg} / \mathrm{L}$, pH: $7.0 \mathrm{As}(\mathrm{III}))$ was achieved after $80 \mathrm{~min}(85 \%)$ with SD/ $\mathrm{MnFe}_{2} \mathrm{O}_{4}$ composites [36]. In this study, less contact time was enough to achieve removal efficiency (98\%) reported by Podder et al. (2015).

The $\mathrm{pH}$ could be an important factor to take into account in the adsorption processes. So, in this study, the $\mathrm{pH}$ effect was eValuated. Figure 7 shows the effect of $\mathrm{pH}$ on the adsorption process with the MNPs of $\mathrm{CoFe}_{2} \mathrm{O}_{4}$ and $\mathrm{MnFe}_{2} \mathrm{O}_{4}$. A similar pattern of As adsorption in all $\mathrm{pH}$ assayed was observed. The maximum adsorption was reached after $10 \mathrm{~min}$, in all cases, probably due to the MNPs negative surface charge, $-90 \mathrm{mV}$ for $\mathrm{CoFe}_{2} \mathrm{O}_{4}$ and $-98 \mathrm{mV}$ for $\mathrm{MnFe}_{2} \mathrm{O}_{4}$. At the $\mathrm{pH}$ range assayed $\left(6,7,8\right.$, and 8.5), the $\mathrm{H}_{3} \mathrm{AsO}_{3}$ is positively charged, which allows us to explain the high efficiency of the As (III) removal.

The As(III) adsorption capacity remained similar in the range of the $\mathrm{pH}$ studied; this is possible because of the lack of competition with the hydroxyl groups (OH-) that were generated during the adsorption processes [29], keeping the MNPs' adsorption sites active as well as the non-deprotonation [7]. Alternatively, this is probably because it involves a two-step ligand exchange reaction: First, the hydroxyl group of the metal hydroxide is protonated; then, the $\mathrm{H}_{2} \mathrm{O}$ ligand is replaced with the oxyanion, so the adsorption is affected by protonation of the $\mathrm{pH}$-dependent metal hydroxide surfaces because the affinity differences of the adsorption between the oxyanion species are generally small. This is usually attributed to the metal hydroxides' surface deprotonation with the increased $\mathrm{pH}$ [37]. Thus, the surfaces of our MNPs play an essential role in the electrostatic interaction for the ligands exchange. 


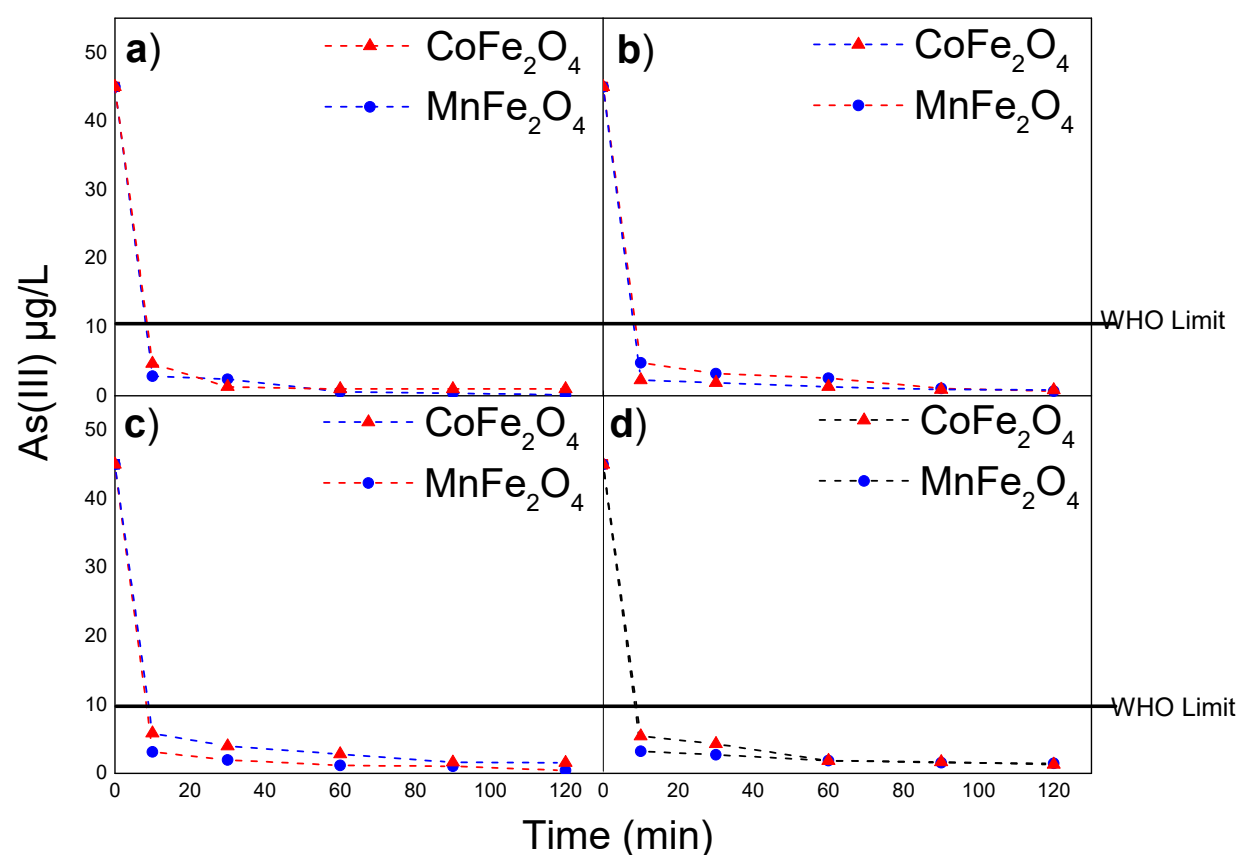

Figure 7. $\mathrm{pH}$ effect on the adsorption with $\mathrm{CoFe}_{2} \mathrm{O}_{4}, \mathrm{MnFe}_{2} \mathrm{O}_{4}$, (a) $\mathrm{pH}$ 6, (b) $\mathrm{pH} 7$, (c) $\mathrm{pH} 8$, and (d) $\mathrm{pH}$ 8.5. As(III) $\mathrm{Ci} 45 \mu \mathrm{g} / \mathrm{L}$.

On the other hand, at $\mathrm{pH} 8$, the highest adsorption capacity was reached with $\mathrm{CoFe}_{2} \mathrm{O}_{4}$ (Figure 8c), achieving a removal efficiency of $99.7 \%$. Furthermore, it is important to notice that more than $90 \%$ adsorption is achieved with the two synthesized nanomaterials, and the results can be attributed to the protection of negatively charged sites on the surface of the MNPs.

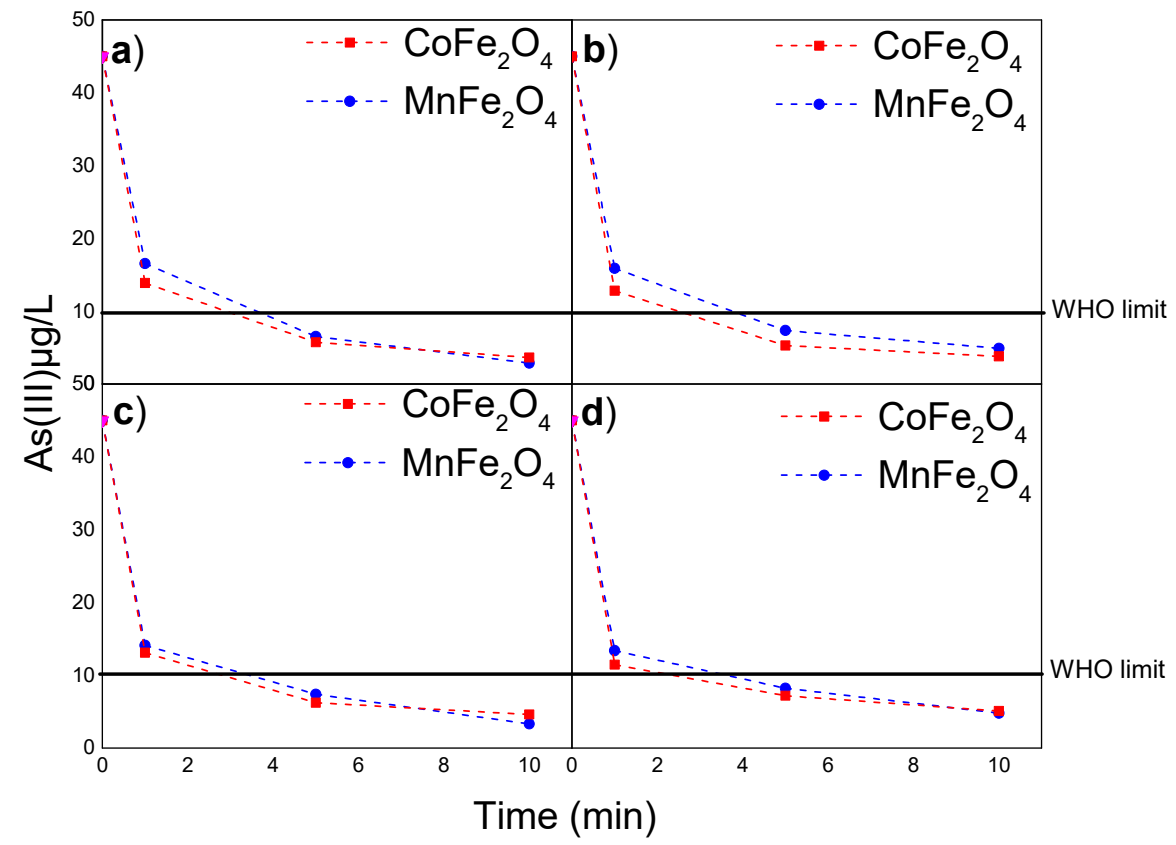

Figure 8. Contact time (1,5, and $10 \mathrm{~min})$ effect at different $\mathrm{pH}$ on the $\mathrm{As}(\mathrm{III})$ adsorption with $\mathrm{CoFe}_{2} \mathrm{O}_{4}$ and $\mathrm{MnFe}_{2} \mathrm{O}_{4}$ at (a) $\mathrm{pH}$ 6, (b) $\mathrm{pH}$ 7, (c) $\mathrm{pH} 8$, and (d) $\mathrm{pH} 8.5$, with an initial As concentration of $45 \mu \mathrm{g} / \mathrm{L}$.

As shown in Figure 8, during the first minute of contact, As ions removal achieves $80 \%$ in the $\mathrm{pH}$ range studied, and the greatest As removal was observed during the first 
$10 \mathrm{~min}$. So, As removal through these nanomaterials is swift, and it could be attributed to the strong affinity of the MNPs iron ions. However, it could also be due to the adsorbents' high specific surface area, which had enough active sites to carry out the adsorption.

Some authors $[38,39]$ reported removal efficiencies around $85 \%$ in contact times between 30 and $120 \mathrm{~min}$. However, in this study, the MNPs synthesized showed higher $\mathrm{As}$ (III) removal efficiency in less time (10 min), eVen at different $\mathrm{pH}$.

As Figure 8 shows, the As(III) adsorption efficiencies for the two nanomaterials were more than $90 \%$. eVen at the first $5 \mathrm{~min}$, the final As concentration was below the limit proposed by the World Health Organization (WHO, $10 \mu \mathrm{g} / \mathrm{L}$ ). Moreover, Figure 8 shows that the MNPs' adsorption capacity is independent of the solution $\mathrm{pH}$, at least in the range of 6 to 8.5. Likewise, it can be noticed that the As adsorption rate during the first minute is higher than the rate obtained from minute 2 onwards and decreases as time goes by. This may be because the available adsorption sites become saturated as time passes.

Natural water composition varies depending on the sampling site, therefore the ions in the natural water are characteristic of the region and can be a significant factor in the water treatment process. To determine if the occurrence of these ions would affect the MNPs' arsenic adsorption efficiency, well water samples were taken, and the concentration of the majority cations found in groundwater samples was $\mathrm{Na}$ (as $\mathrm{NaCl}, 60 \mathrm{mg} / \mathrm{L}$ ), $\mathrm{K}$ (as $\mathrm{KCl}, 57 \mathrm{mg} / \mathrm{L}$ ), $\mathrm{Ca}$ (as CaCl, $52 \mathrm{mg} / \mathrm{L}$ ), and $\mathrm{Mg}$ (as $\mathrm{MgCl}, 2 \mathrm{mg} / \mathrm{L}$ ).

Figure 9a shows the competing cations found in Durango's groundwater $\left(\mathrm{Na}^{+}, \mathrm{K}^{+}\right.$, $\mathrm{Mg}^{+}$, and $\mathrm{Ca}^{+}$) and their effect on As (III) adsorption, using $\mathrm{CoFe}_{2} \mathrm{O}_{4}$. eVen if the present ions can compete directly for the surface adsorption sites and indirectly influence the As (III) adsorption by altering the electrostatic charge of the solid surface, their presence did not have a detrimental effect on As (III) adsorption capacity of $\mathrm{CoFe}_{2} \mathrm{O}_{4}$. In contrast, competition with $\mathrm{Mg}+$ was observed when $\mathrm{MnFe}_{2} \mathrm{O}_{4}$ was used for As (III) removal, and this could be attributed to both similar charge properties at the working $\mathrm{pH}(\mathrm{pH} 8)$. However, this was observed only in the presence of $\mathrm{Mg}^{+}$and not for the other cations $\left(\mathrm{Na}^{+}, \mathrm{K}^{+}\right.$, and $\mathrm{Ca}^{+}$) (Figure 9b).

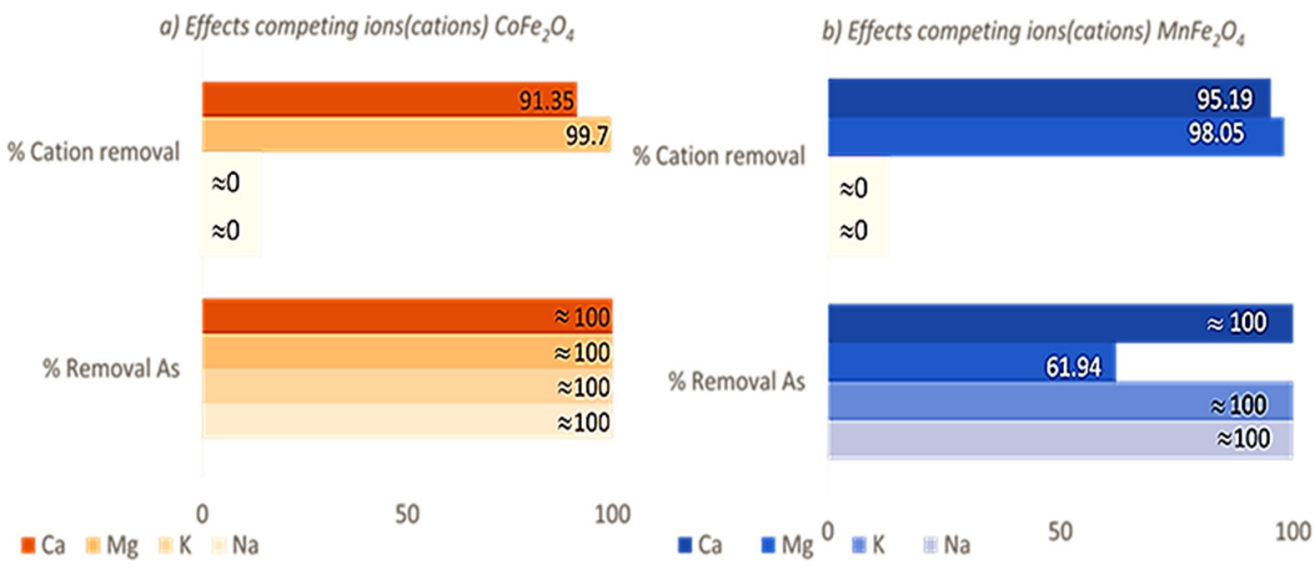

Figure 9. Competing ions removal and effect on the As (III) removal (Ci $33 \mu \mathrm{g} / \mathrm{L}$ ) with (a) $\mathrm{CoFe}_{2} \mathrm{O}_{4}$ and (b) $\mathrm{MnFe}_{2} \mathrm{O}_{4}$ as the absorbent.

As adsorption efficiency in groundwater samples was calculated from the maximum adsorption capacity $(\mathrm{Qm})$, the results are presented in Figure 10 for $\mathrm{CoFe}_{2} \mathrm{O}_{4}$. The initial sample $\mathrm{pH}$ was 7.9 , and the final $\mathrm{pH}$ was 8.1. The $\mathrm{pH}$ is a significant variable in the adsorption process because it can cause interference between the ions in the solution and the MNPs' surface [29]. 


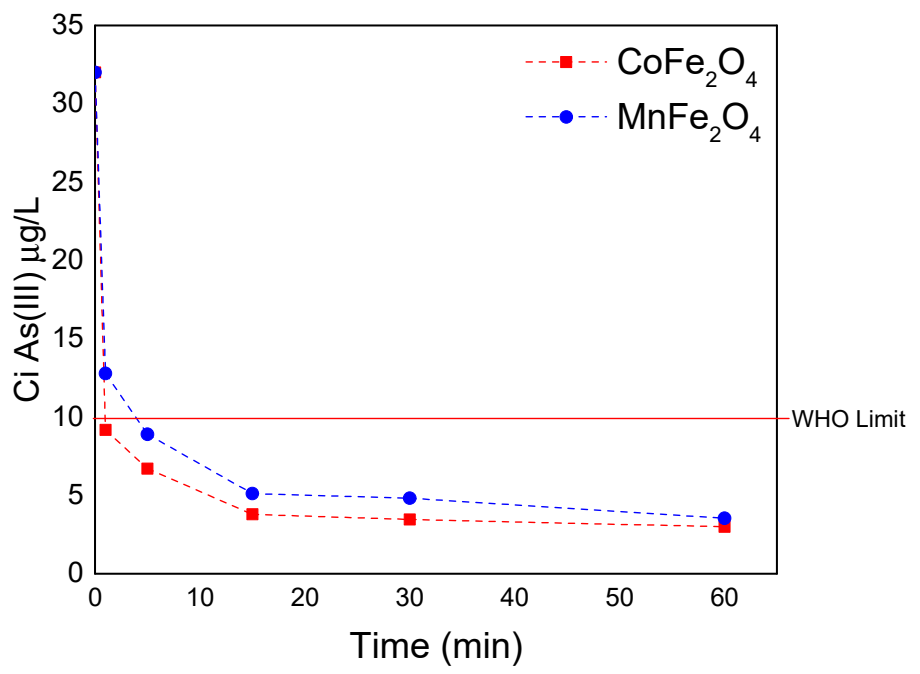

Figure 10. As adsorption in groundwater using $\mathrm{CoFe}_{2} \mathrm{O}_{4}$ and $\mathrm{MnFe}_{2} \mathrm{O}_{4}$.

The maximum adsorption occurs in the first ten minutes until a value of $89 \%$ is reached at $15 \mathrm{~min}$; this could be due to the presence of $\mathrm{HCO}_{3}^{-}$, which could generate competition for As (III) adsorption.

The As adsorption with $\mathrm{MnFe}_{2} \mathrm{O}_{4}$ decays by $1 \%$ compared to the results achieved with $\mathrm{CoFe}_{2} \mathrm{O}_{4}$. The equilibrium was reached after $30 \mathrm{~min}$ with a final adsorption percentage of $88 \%$, and a final As concentration $\left(\mathrm{C}_{\mathrm{F}}\right)$ below $5 \mu \mathrm{g} / \mathrm{L}$, making $\mathrm{MnFe}_{2} \mathrm{O}_{4}$ a suitable material for water treatment technologies for human consumption, because the final As concentrations achieved were in accordance with the NOM-127-SSA1-1994 (2000) and the World Health Organization limits. Therefore, $\mathrm{CoFe}_{2} \mathrm{O}_{4}$ and $\mathrm{MnFe}_{2} \mathrm{O}_{4}$ are highly promising MNPs for groundwater As removal in compliance with water quality As-permissible limits.

\subsection{Adsorption Kinetics Study}

In this study, As (III) adsorption kinetics were performed to explore the adsorption rate. Figure 11a shows the changes of As (III) concentration in the solution against time for $\mathrm{CoFe}_{2} \mathrm{O}_{4}$ and $\mathrm{MnFe}_{2} \mathrm{O}_{4}$. The As (III) adsorption was fast in the first $10 \mathrm{~min}$, then it slowed down until the equilibrium was reached, at $30 \mathrm{~min}$. The quick initial As (III) adsorption could be due to the nanoscale particle size of the adsorbents, since the fine particles favored the As (III) diffusion from the solution towards the active sites of the adsorbents [40]. First- and second-order equations [41] were used to describe the As (III) adsorption in these MNPs, and the best linear fit was obtained with the second-order reaction model (Figure 11b).

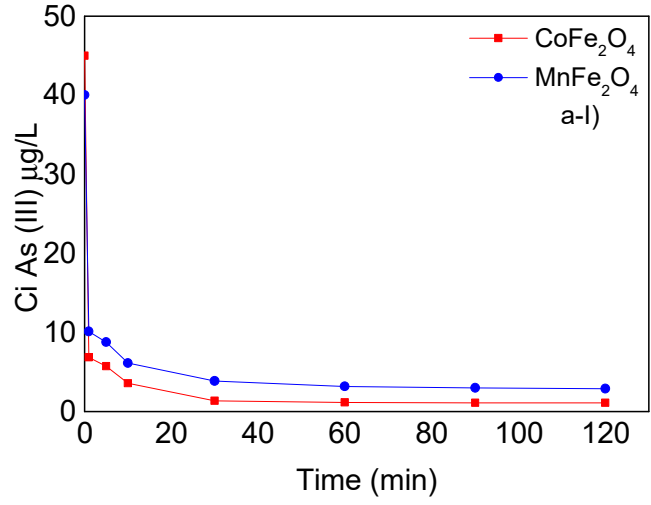

(a)

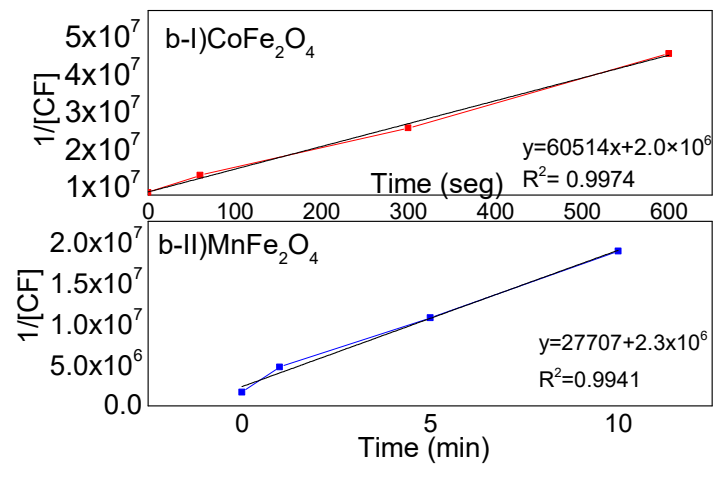

(b)

Figure 11. (a) Adsorption kinetics of $\mathrm{As}$ (III) for $\mathrm{CoFe}_{2} \mathrm{O}_{4}$ and $\mathrm{MnFe}_{2} \mathrm{O}_{4},(0.1 \mathrm{~g} / \mathrm{L}) \mathrm{pH} 8$; (b) second-order kinetic graph for As (III). 
The second-order rate constants for As (III) adsorption with $\mathrm{CoFe}_{2} \mathrm{O}_{4}$ and $\mathrm{MnFe}_{2} \mathrm{O}_{4}$ are shown in Table 2.

Table 2. Kinetic constants.

\begin{tabular}{|c|c|c|c|c|}
\hline Kinetic Model & Equation & Constant & Value $\mathrm{CoFe}_{2} \mathrm{O}_{4}$ & Value $\mathrm{MnFe}_{2} \mathrm{O}_{4}$ \\
\hline First order & $\mathrm{Ln} C \mathrm{t}=\mathrm{Ln} \mathrm{Co}-\mathrm{K} \times \mathrm{t}$ & $\begin{array}{c}\mathrm{K} \\
\left(\mathrm{R}^{2}\right)\end{array}$ & $\begin{array}{c}17.47 \\
(0.8576)\end{array}$ & $\begin{array}{c}16.75 \\
(0.8532)\end{array}$ \\
\hline Second order * & $\frac{1}{C_{t}}=K \cdot t+\frac{1}{C_{o}}$ & $\begin{array}{c}\mathrm{K} \\
\left(\mathrm{R}^{2}\right)\end{array}$ & $\begin{array}{c}6.66 \times 10^{113} \\
(0.99)\end{array}$ & $\begin{array}{c}8.33 \times 10^{27} \\
(0.99)\end{array}$ \\
\hline
\end{tabular}

* Where $\mathrm{Ct}(\mu \mathrm{g} / \mathrm{L})$ is the concentration of As in the solution at time $\mathrm{t}$ (minutes), $\mathrm{Co}(\mu \mathrm{g} / \mathrm{L})$ is the initial concentration of As, and $\mathrm{K}$

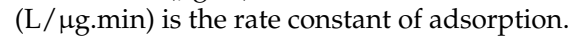

The As adsorption isotherms were carried out at $\mathrm{pH} 7$ with initial As concentrations (Ci) of $25,45,65$, and $75 \mu \mathrm{g} / \mathrm{L}$ in $100 \mathrm{~mL}$; the adsorbent dose was $0.1 \mathrm{~g} / \mathrm{L}$, and the contact times were 1, 5, 10, 30, and $60 \mathrm{~min}$. The Langmuir and Freundlich models were used to adjust the data, and the correlation coefficient $\left(\mathrm{R}^{2}\right)$ was used to compare and determine the best model of adjustment. The adsorption isotherms of As (III) ions on MNPs are shown in Figure A2. Table 3 shows the parameters related to the Langmuir and Freundlich isotherms for the two MNP samples.

Table 3. Values for the Langmuir and Freundlich isotherms.

\begin{tabular}{ccccccc}
\hline \multirow{2}{*}{ MNPs } & \multicolumn{2}{c}{ Langmuir } & \multicolumn{3}{c}{ Freundlich } \\
\cline { 3 - 7 } & & $\mathbf{Q m}(\mathbf{m g} / \mathbf{g})$ & $\mathbf{R}^{\mathbf{2}}$ & $\mathbf{K F}(\mathbf{m g} / \mathbf{g})$ & $\mathbf{n}$ & $\mathbf{R}^{\mathbf{2}}$ \\
\hline \multirow{2}{*}{ As (III) } & $\mathrm{CoFe}_{2} \mathrm{O}_{4}$ & 250 & 0.99 & 1.27 & 0.28 & 0.98 \\
\cline { 2 - 7 } & $\mathrm{MnFe}_{2} \mathrm{O}_{4}$ & 238.1 & 0.99 & 1.38 & 0.29 & 0.98 \\
\hline
\end{tabular}

The regression coefficient $\left(\mathrm{R}^{2}\right)$ obtained in both cases was higher than 0.99 , which indicates that the isotherm models were adequate to describe the adsorption behavior of the As ions on the MNPs; eVen for the Freundlich model, the $\mathrm{R}^{2}$ was 0.99, which suggests the occurrence of a multilayer/physical adsorption process. Thus, the application of the Langmuir isotherm model is limited to monolayer adsorption on the adsorbate-adsorbent surface. On the other hand, the Freundlich model is an empirical equation based on the multilayer adsorption of an adsorbate on heterogeneous surfaces.

The maximum adsorption capacity was calculated from the Langmuir isotherm and was 250 for $\mathrm{CoFe}_{2} \mathrm{O}_{4}$ and $238 \mathrm{mg} / \mathrm{g}$ for $\mathrm{MnFe}_{2} \mathrm{O}_{4}$. The synthesized nanomaterials of $\mathrm{CoFe}_{2} \mathrm{O}_{4}$ and $\mathrm{MnFe}_{2} \mathrm{O}_{4}$, which possess a high ion adsorption capacity of As (III) ions, were convenient for the As (III) adsorption, likewise with an easy recovery with magnetic separation.

In the subsequent calculation, a substantial adjustment to both models is discernible $\left(\mathrm{R}^{2}=0.99\right)$. The maximum adsorption capacity for short times does not change significantly in the Langmuir model, at 222.22 and 105.26, $\mathrm{mg} / \mathrm{g}$ for $\mathrm{CoFe}_{2} \mathrm{O}_{4}$ and $\mathrm{MnFe}_{2} \mathrm{O}_{4}$, respectively. In the Freundlich model for $\mathrm{MnFe}_{2} \mathrm{O}_{4}(2.04 \mathrm{mg} / \mathrm{g})$, a sudden change is observed, and $\mathrm{CoFe}_{2} \mathrm{O}_{4}$ remains at $1.38 \mathrm{mg} / \mathrm{g}$. These subsequent studies demonstrate that the synthesized materials possess a high adsorption capacity for metal ions, specifically As (III), in shorter contact times than those reported [38-42].

Proposed Mechanism

Based on the operating conditions and isotherms, the $\mathrm{CoFe}_{2} \mathrm{O}_{4}$ adsorption capacity was greater than that for $\mathrm{MnFe}_{2} \mathrm{O}_{4}$. This result can be explained by the material's properties, such as the smaller size and greater surface area. When cobalt oxide $(\mathrm{CoO})$ comes in contact with water, it could cause water hydrolysis (water molecule dissociation) because iron oxides' $\mathrm{pH}$ is basic. When water is dissociated, the $\mathrm{OH}^{-}$ions bind to the metal (Co and $\mathrm{Mn}$ ), and the $\mathrm{H}^{+}$ions bind to oxygen (hydroxylation), causing a surface change on the adsorbent 
surfaces depending on the $\mathrm{pH}$. Considering the reactions that take place, reaction 1 ( $\mathrm{Rx} 1$ ) represents the hydrated adsorbent surface, and depending on the $\mathrm{pH}$, the adsorbent surface can be either positively or negatively charged; reaction 2 represents what happens with the adsorbent surface charge in the basic medium.

$$
\begin{gathered}
\mathrm{CoO}(\mathrm{OH})_{\mathrm{s}}+\mathrm{H}_{2} \mathrm{O}_{\mathrm{L}} \rightarrow \mathrm{CoFe}^{2}+3 \mathrm{OH}^{-} \\
\mathrm{CoFe}(\mathrm{OH})_{3} \leftrightarrow \mathrm{CoFe}(\mathrm{OH})_{2}^{+}+\mathrm{OH}^{-}
\end{gathered}
$$

$\mathrm{CoO}$ could be replaced by $\mathrm{MnO}$ for the other adsorbents studied.

Furthermore, according to the As adsorption mechanism (physisorption), the As ions were adsorbed to the surface of $\mathrm{CoFe}_{2} \mathrm{O}_{4}$ by weak forces that include the oxygen-metal bridge and van der Waals [42]. In addition, it was reported that electron-rich atoms such as oxygen could interact with a metal/oxide site to form an intermediate bridge called the oxygen-metal bridge [43]. Because these types of forces are weak, adsorption on these materials can be reversible.

\section{Discussion}

The use of magnetic nanoparticles provides an opportunity to solve problems derived from water contamination, including solutions related to bacteria, viruses, and pesticides removal.

The As adsorption capacities in MNPs are firmly attributed to their properties, for instance their surface area is one of the main factors that assist As adsorption. $\mathrm{CoFe}_{2} \mathrm{O}_{4}$ and $\mathrm{MnFe}_{2} \mathrm{O}_{4}$ presented higher surface area values (198.6 and $188.8 \mathrm{~m}^{2} / \mathrm{g}$, respectively) to which the best performance in terms of the adsorption capacity of As ions in groundwater is attributed. Previous works [15-21] report 96\% removal of As using adsorbents such as $\mathrm{CoFe}_{2} \mathrm{O}_{4}$ and $93 \%$ for $\mathrm{MnFe}_{2} \mathrm{O}_{4}$; however, the operating conditions are entirely different $(0.2 \mathrm{~g} / \mathrm{L}$ dose and in $8 \mathrm{~h}$ of contact time), which demonstrate that the MNPs reported in this work are more technically feasible. Magnetic adsorbents are ideal since they have a high adsorption capacity for As, and in terms of their magnetic properties, they are easy to separate from water. Additionally, the adsorption of As (III) for these MNPs is very fast, reaching the equilibrium time in less than $30 \mathrm{~min}$; experiments by Saidur R et al., 2010 report the equilibrium within $24 \mathrm{~h}$.

\section{Conclusions}

The adsorption capacity of $\mathrm{CoFe}_{2} \mathrm{O}_{4}$ and $\mathrm{MnFe}_{2} \mathrm{O}_{4}$, synthesized by the chemical coprecipitation method, supports their potential application for As (III) removal from water to below the WHO recommended value of $10 \mu \mathrm{g} / \mathrm{L}$.

In this study, $\mathrm{CoFe}_{2} \mathrm{O}_{4}$ and $\mathrm{MnFe}_{2} \mathrm{O}_{4}$ showed excellent adsorption capacities. This could be due to the several surface hydroxyls groups and other morphological characteristics, such as their size and greater surface area, creating more adsorbing sites.

The zeta potential change in the MNPs at $\mathrm{pH}>2$ implies the formation of groups with a negative charge on the surface of the MNPs. The $\mathrm{pH}$ has no significant effect on As (III) adsorption in the worked range.

As a promising perspective, MNPs demonstrated a high capacity to remove As from water, eVen at the presence of several ions (as $\mathrm{Ca}, \mathrm{Mg}$, $\mathrm{Na}$, and $\mathrm{K}$, among others), allowing their potential application in continuous flow systems. Moreover, arsenic can be desorbed from the MNPs with a $\mathrm{NaOH}$ solution, and the adsorbents could be separated from the solution using magnetic filtration processes. This issue should be addressed in upcoming work.

Author Contributions: Conceptualization, L.R.-C., L.L.-J., C.G.M.-A. and M.T.A.-H.; investigation, C.G.M.-A., L.R.-C., L.L.-J. and S.A.L.-M.; methodology, C.G.M.-A., L.R.-C., L.L.-J. and S.A.L.-M.; project administration, L.R.-C., L.L.-J. and M.T.A.-H.; writing-original draft, L.R.-C., L.L.-J., C.G.M.A., S.A.L.-M., P.D.A.-S. and M.T.A.-H.; writing-review and editing, L.R.-C., L.L.-J., C.G.M.-A., S.A.L.-M., P.D.A.-S. and M.T.A.-H. All authors have read and agreed to the published version of the manuscript. 
Funding: This work was supported by Project No. 267666 of the FONCICYT CONACYT-INNOVATE UK 2015. Likewise, thanks to FORDECYT project No. 297116: “Water Consortium." To CONACYT for its support with the scholarship 486760.

Acknowledgments: To M.S.A Luis Arturo Torres-Castañón, for all the analytical facilities and collaboration in analytical determinations.

Conflicts of Interest: The authors declare no conflict of interest.

\section{Appendix A}

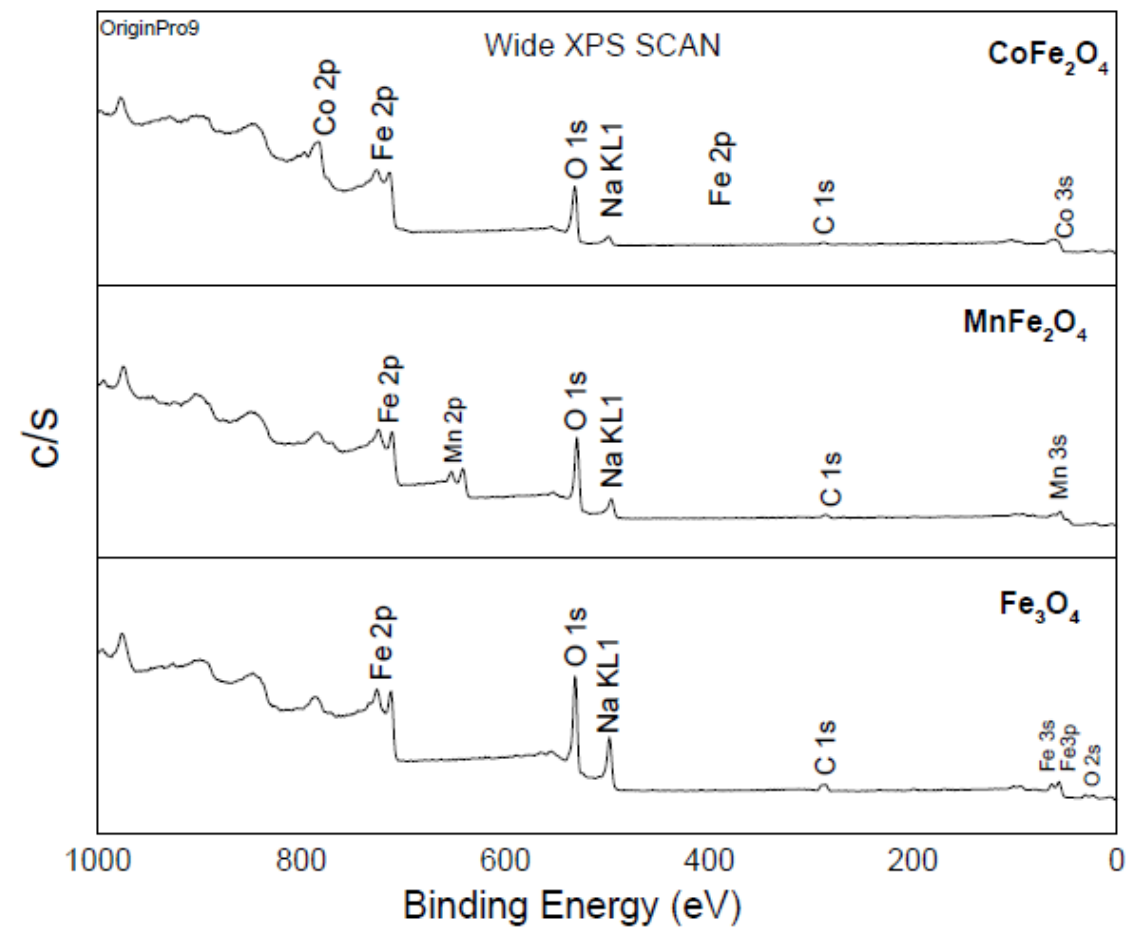

Figure A1. Wide XPS scan.
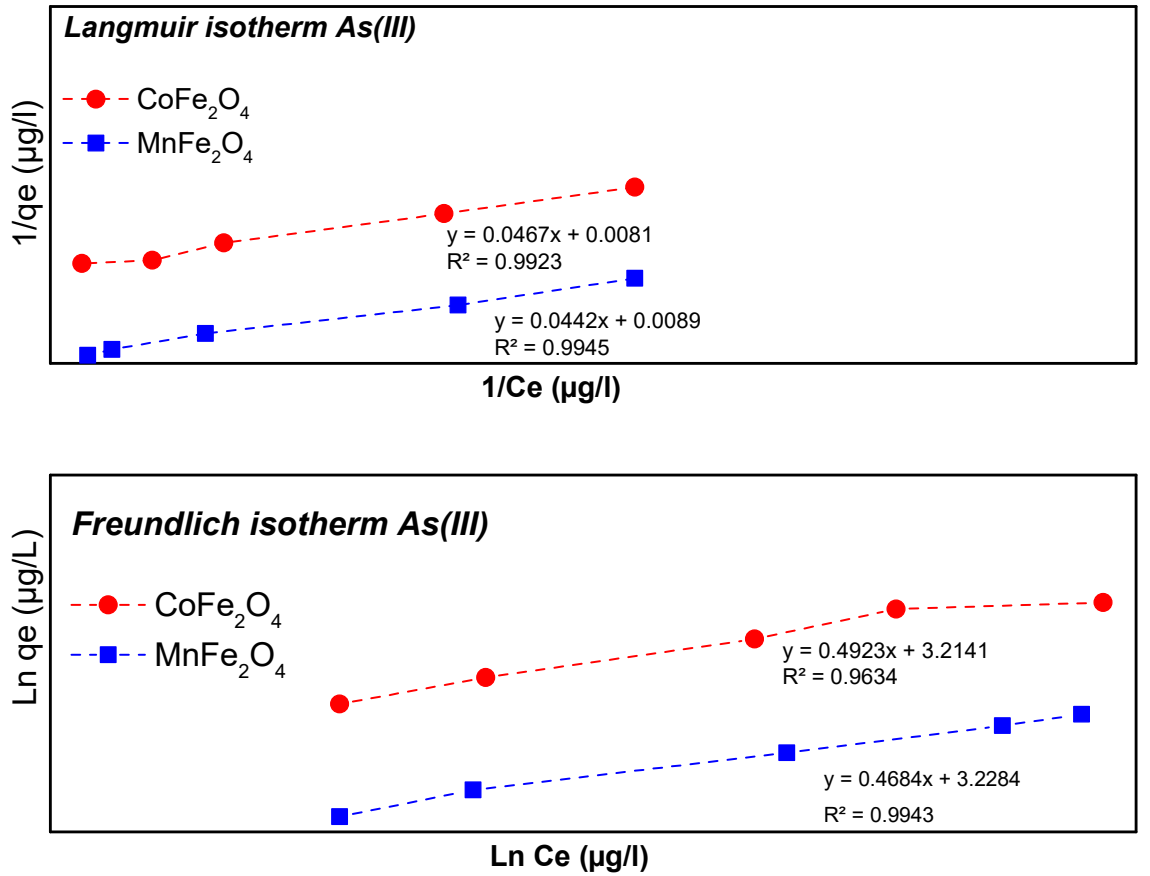

Figure A2. Langmuir and Freundlich isotherms for the MNPs samples. 


\section{References}

1. Flora, S.J.S. Arsenic: Chemistry, Occurrence, and Exposure. In Handbook of Arsenic Toxicology; Academic Press: Cambridge, MA, USA, 2015; pp. 1-49. [CrossRef]

2. Litter, M.I.; Morgada, M.E.; Bundschuh, J. Possible treatments for arsenic removal in Latin American waters for human consumption. Environ. Pollut. 2020, 158, 1105-1118. [CrossRef]

3. Das, N.; Khanikar, L.; Shah, R.; Das, A.; Goswami, R.; Kumar, M.; Sarma, K.P. Problem, perspective and challenges of arsenic contamination in the groundwater of brahmaputra flood plains and barak valley regions of assam, india. In Safe Sustain Use Arsenic-Contaminated Aquifers Gangetic Plain A Multidiscip; Springer: Berlin/Heidelberg, Germany, 2015. [CrossRef]

4. Kumar, M.; Rahman, M.M.; Ramanathan, A.; Naidu, R. Arsenic and other elements in drinking water and dietary components from the middle Gangetic plain of Bihar, India. Sci. Total Environ. 2016, 539, 125-134. [CrossRef]

5. Martinez-Miranda, M.M.; Rosero-Moreano, M.; Taborda-Ocampo, G. Occurrence, dietary exposure and risk assessment of aflatoxins in arepa, bread and rice. Food Control 2019, 98, 359-366. [CrossRef]

6. Lou, J.; Yu, D.; Hristovski, K.D.; Fu, K.; Shen, Y.; Westerhoff, P.; Crittenden, J.C. Critical Review of Advances in Engineering Nanomaterial Adsorbents for Metal Removal and Recovery from Water: Mechanism Identification and Engineering Design. Environ. Sci. Technol. 2021, 55, 4287-4304. [CrossRef]

7. Kameda, T.; Suzuki, Y.; Yoshioka, T. Removal of arsenic from an aqueous solution by coprecipitation with manganese oxide. $J$. Environ. Chem. Eng. 2014, 2, 2045-2049. [CrossRef]

8. Tag El-Din, A.F.; El-Khouly, M.E.; Elshehy, E.A. Cellulose acetate assisted synthesis of worm-shaped mesopores of MgP ionexchanger for cesiumions removal from seawater. Microporous Mesoporous Mater. 2018, 265, 211-218. [CrossRef]

9. Glass, S.; Mantel, T.; Appold, M.; Sen, S.; Usman, M.; Ernst, M.; Filiz, V. Amine-Terminated PAN Membranes as Anion-Adsorber Materials Chem. Ing. Tech. 2021, 93, 1396-1400. [CrossRef]

10. Lam, B.; Déon, S.; Crini, N.M.; Crini, G.; Fievet, P. Polymerenhanced ultrafiltration for heavy metal removal: Influence of chitosan and carboxymethyl cellulose on filtration performances. J. Clean Prod. 2018, 171, 927-933. [CrossRef]

11. López Guzmán, M.; Alarcón Herrera, M.T.; Irigoyen-Campuzano, J.R.; Torres-Castañón, L.A.; Reynoso-Cuevas, L. Simultaneous removal of fluoride and arsenic from well water by electrocoagulation. Sci. Total Environ. 2019, 678, 181-187. [CrossRef]

12. Abejón, A.; Garea, A.; Irabien, A. Arsenic removal from drinking water by reverse osmosis: minimization of costs and energy consumption. Sep. Purif. Technol. 2015, 144, 46-53. [CrossRef]

13. Bensaadi, S.; Nasrallah, N.; Amrane, A.; Trari, M.; Kerdjoudj, H.; Arous, O.; Amara, M. Dialysis and photo-electrodialysis processes using new synthesized polymeric membranes for the selective removal of bivalent cations. J. Environ. Chem. Eng. 2017, 5, 1037-1047. [CrossRef]

14. Barakat, M.A. New trends in removing heavy metals from industrial wastewater. Arab. J. Chem. 2011, 4, 361-377. [CrossRef]

15. Fu, F.; Wang, Q. Removal of heavy metal ions from wastewaters: A review. J. Environ. Manag. 2011, 92, 407-418. [CrossRef] [PubMed]

16. Khorzughy, S.H.; Eslamkish, T.; Ardejani, F.D.; Heydartaemeh, M.R. Cadmium removal from aqueous solutions by pumice and nanopumice. Korean J. Chem. Eng. 2015, 32, 88-96. [CrossRef]

17. Nguyen, T.A.H.; Ngo, H.H.; Guo, W.S.; Zhang, J.; Liang, S.; Yue, Q.Y.; Li, Q.T.V. Nguyen Applicability of agricultural waste and byproducts for adsorptive removal of heavy metals from wastewater. Bioresour. Technol. 2013, 148, 574-585. [CrossRef] [PubMed]

18. Thanh, D.N.; Novák, P.; Vejpravova, J.; Vu, H.N.; Lederer, J.; Munshi, T. Removal of copper and nickel from water using nanocomposite of magnetic hydroxyapatite nanorods. J. Magn. Magn. Mater. 2018, 456, 451-460. [CrossRef]

19. Zhang, J.; Lin, S.; Han, M.; Su, Q.; Xia, L.; Hui, Z. Adsorption properties of magnetic magnetite nanoparticle for coexistent Cr (VI) and $\mathrm{Cu}$ (II) in mixed solution. Water 2020, 12, 446. [CrossRef]

20. Nikic, J.; Tubic, A.; Watson, M.; Maletic, S.; Solic, M.; Majkic, T.; Agbaba, J. Arsenic Removal from Water by Green Synthesized Magnetic Nanoparticles. Water 2019, 11, 2520. [CrossRef]

21. Bee, A.; Massart, R.; Neveu, S. Synthesis of very fine maghemite particles. J. Magn. Magn. Mater. 1995, 149, 6-9. [CrossRef]

22. Sahoo, S.; Sahoo, P.K.; Sharma, A.; Satpati, A.K. Interfacial polymerized RGO/MnFe2O4/polyaniline fibrous nanocomposite supported glassy carbon electrode for selective and ultrasensitive detection of nitrite. Sens. Actuators B Chem. 2020, $309,127763$. [CrossRef]

23. Yue, L.; Zhang, S.; Zhao, H.; Feng, Y.; Wang, M.; An, L.; Zhang, X.; Mi, J. One-pot synthesis CoFe2O4/CNTs composite for asymmetric supercapacitor electrode. Solid State Ion. 2019, 329, 15-24. [CrossRef]

24. Yao, Y.; Cai, Y.; Lu, F.; Wei, F.; Wang, X.; Wang, S. Magnetic recoverable $\mathrm{MnFe}_{2} \mathrm{O}_{4}$ and $\mathrm{MnFe}_{2} \mathrm{O}_{4}$-graphene hybrid as heterogeneous catalysts of peroxymonosulfate activation for efficient degradation of aqueous organic pollutants. J. Hazard. Mater. 2014, 270, 61-70. [CrossRef] [PubMed]

25. Nilmoung, S.; Kidkhunthod, P.; Maensiri, S. The structural and electrochemical properties of CNF/MnFe $2 \mathrm{O}_{4}$ composite nanostructures for supercapacitors. Mater. Chem. Phys. 2018, 220, 190-200. [CrossRef]

26. Li, B.; Cao, H.; Shao, J.; Qu, M. Enhanced anode performances of the $\mathrm{Fe}_{3} \mathrm{O}_{4}$-Carbon-rGO three dimensional composite in lithium ion batteries. Chem. Commun. 2011, 47, 10374-10376. [CrossRef] [PubMed]

27. Wang, W.; Ding, Z.; Zhao, X.; Wu, S.; Li, F.; Yue, M.; Liu, J.P. Microstructure and magnetic properties of MFe2O4 (M = Co, Ni, and $\mathrm{Mn}$ ) ferrite nanocrystals prepared using colloid mill and hydrothermal method. J. Appl. Phys. 2015. [CrossRef] 
28. Pankhurst, Q.A.; Connolly, J.; Jones, S.K.; Dobson, J. Applications of magnetic nanoparticles in biomedicine. J. Phys. D. Appl. Phys. 2003, 117, 17A328. [CrossRef]

29. Illés, E.; Tombácz, E. The effect of humic acid adsorption on pH-dependent surface charging and aggregation of magnetite nanoparticles. J. Colloid Interface Sci. 2006, 295, 115-123. [CrossRef]

30. $\mathrm{Hu}, \mathrm{H} . ; \mathrm{Xu}, \mathrm{K}$. Physicochemical technologies for HRPs and risk control. In High-Risk Pollution Wastewater; Elsevier University: Nanjing, China, 2019; pp. 169-207. [CrossRef]

31. Yang, J.C.; Yin, X.B. CoFe $\mathrm{O}_{4} @$ MIL-100(Fe) hybrid magnetic nanoparticles exhibit fast and selective adsorption of arsenic with high adsorption capacity. Sci. Rep. 2017, 7, 40955. [CrossRef]

32. Asadi, R.; Abdollahi, H.; Gharabaghi, M.; Boroumand, Z. Effective removal of Zn (II) ions from aqueous solution by the magnetic $\mathrm{MnFe}_{2} \mathrm{O}_{4}$ and $\mathrm{CoFe}_{2} \mathrm{O}_{4}$ spinel ferrite nanoparticles with focuses on synthesis, characterization, adsorption, and desorption. Adv. Powder Technol. 2020, 31, 1480-1489. [CrossRef]

33. Zhang, S.; Niu, H.; Cai, Y.; Zhao, X.; Shi, Y. Arsenite and arsenate adsorption on coprecipitated bimetal oxide magnetic nanomaterials: $\mathrm{MnFe}_{2} \mathrm{O}_{4}$ and $\mathrm{CoFe}_{2} \mathrm{O}_{4}$. Chem. Eng. J. 2010, 158, 599-607. [CrossRef]

34. Secretaría de Salud, NOM-127-SSA1-1994, Salud Ambiental, Agua Para uso y Consumo Humano-Límites Permisibles de Calidad y Tratamientos a que debe Someterse el Agua para su Potabilización; Diario Oficial de la Federación: Ciudad de México, México. 1994; pp. 1-5. Available online: http://www.salud.gob.mx/unidades/cdi/nom/127ssa14.html (accessed on 9 September 2021).

35. Iconaru, S.L.; Guégan, R.; Popa, C.L.; Motelica-Heino, M.; Ciobanu, C.S.; Predoi, D. Magnetite $\left(\mathrm{Fe}_{3} \mathrm{O}_{4}\right)$ nanoparticles as adsorbents for As and Cu removal. Appl. Clay Sci. 2016, 134, 128-135. [CrossRef]

36. Podder, M.S.; Majumder, C.B. SD/ $\mathrm{MnFe}_{2} \mathrm{O}_{4}$ composite, a biosorbent for $\mathrm{As}(\mathrm{III})$ and $\mathrm{As}(\mathrm{V})$ removal from wastewater: Optimization and isotherm study. J. Mol. Liq. 2015, 212, 382-404. [CrossRef]

37. Maji, S.K.; Pal, A.; Pal, T. Arsenic removal from real-life groundwater by adsorption on laterite soil. J. Hazard. Mater. 2008, 151, 811-820. [CrossRef] [PubMed]

38. Maiti, A.; DasGupta, S.; Basu, J.K.; De, S. Adsorption of arsenite using natural laterite as adsorbent. Sep. Purif. Technol. 2007, 55, 350-359. [CrossRef]

39. Reddy, K.J.; McDonald, K.J.; King, H. A novel arsenic removal process for water using cupric oxide nanoparticles. J. Colloid Interface Sci. 2013, 397, 96-102. [CrossRef]

40. Zhang, G.S.; Qu, J.H.; Liu, H.J.; Liu, R.P.; Wu, R.C. Preparation and eValuation of a novel Fe Mn binary oxide adsorbent for effective arsenite removal. Water Res. 2007, 41, 1921-1928. [CrossRef]

41. Kim, Y.; Kim, C.; Choi, N.; Rengaraj, S.; Yi, J. Arsenic removal using mesoporous alumina prepared via a templating method. Environ. Sci. Technol. 2004, 38, 924-931. [CrossRef]

42. Van Tran, T.; Cao, V.D.; Nguyen, V.H.; Hoang, B.N.; Vo, D.V.N.; Nguyen, T.D.; Bach, L.G. MIL-53 (Fe) derived magnetic porous carbon as a robust adsorbent for the removal of phenolic compounds under the optimized conditions. J. Environ. Chem. Eng. 2020, 8, 102902. [CrossRef]

43. Tuutijärvi, T.; Lu, J.; Sillanpää, M.; Chen, G. As(V) adsorption on maghemite nanoparticles. J. Hazard. Mater. 2009, 166, 1415-1420. [CrossRef] 